\title{
Gujarat Coriander 3- A Complete Package with High Seed Yield and Aroma
}

\author{
H.B. Patel*, D.G. Patel, P.T. Patel, N.R. Patel, Hitesh Patel and A.U. Amin \\ Seed Spices Research Station, S.D. Agriculture University, Jagudan, Dist. Mehasan, Gujarat \\ *Corresponding author:
}

A B S T R A C T

\begin{tabular}{|l|}
\hline Ke y w o r d s \\
$\begin{array}{l}\text { Linalool content, } \\
\text { Gujarat Coriander } 3 \\
\text { and ISSR marker }\end{array}$ \\
\hline Article Info \\
\hline $\begin{array}{l}\text { Accepted: } \\
\text { 20 July } 2018 \\
\text { Available Online: } \\
\text { 10 August } 2018\end{array}$ \\
\hline
\end{tabular}

Keywords

Linalool content Gujarat Coriander 3 nd ISSR marke

Article Info

Accepted: Available Online: August 2018

\begin{abstract}
A new variety of coriander (Coriandrum sativum L.), Gujarat Coriander 3 (GCo 3) was tested under 12 trials for 6 years across the country. Under Gujarat climatic conditions, GCo 3 had recorded $1501.32 \mathrm{~kg} / \mathrm{ha}$ seed yield, which was 17.00 per cent higher seed yield than check variety Gujarat Coriander 2 (GCo 2). New variety is having excellent aroma in seeds due to 8.36 per cent higher linalool content $(72.16 \%)$ than that of check variety GCo $2(66.59 \%)$. In respect to total volatile oil, GCo 3 was exhibited 4.84, 20.72 and 3.31 per cent higher volatile oil against Hissar Anand, Rcr-728 and G.Co 2, respectively. Against biotic stress new variety was found tolerant than any other check variety. Due to all above salient feature variety was recommended for release in Gujarat state.
\end{abstract}

\section{Introduction}

Coriander (Coriandrum sativum L.) is commonly known as dhana in Gujarati and dhania in hindi belongs to the family Apiaceae. During 2015-16, India has produced 3.14 Lakh tones of coriander seeds from 4.47 lakh hectors with productivity of $703 \mathrm{~kg} / \mathrm{ha}$. During same year, it was grown in 0.88 lakh hectors in Gujarat state which produced 1.38 Lakh tones with productivity of $1566 \mathrm{~kg} / \mathrm{ha}$. In Gujarat state, during the year 2015-16 the area and production of coriander was increased to 330 per cent as compare to the year 2010-11 (Director of Horticulture report, GoG, 2015-
16). From curry powder 4.01 crore rupees revenue generated in the year 2013-14 (Spice Board of India 2015-16). Linalool is naturally occurring terpene alcohol present in coriander. Coriander containing high linalool is always demanding by exporter to make curry powder. Gujarat Coriander 3 (GCo 3) a new coriander variety was recommended for release after 28 years in Gujarat state. A new variety is having excellent aroma in seed due to 8.36 percent higher linalool content in seed than that of Gujarat coriander 2 (State check variety). New variety GCo 3 was tested as a code Jcr-404 under 12 trials for 6 years across the country and recorded $1668.14 \mathrm{~kg} / \mathrm{ha}$ seed yield, which 
was 14.91 per cent and 24.91 per cent over two respective national checks i.e. Hissar Anand and Rcr 728. New culture was exhibited $1501.32 \mathrm{~kg} / \mathrm{ha}$ seed yield which was 17.0 per cent higher than that of state check variety. In addition to this, Gco 3 was performed seven times, nine times and five times significantly superior over check varieties viz., Hissar Anand, Rcr 728 and GCo 2 , respectively. With new culture 16.36 per cent more volatile oil yield (lt./ha) was harvested due to 3.31 per cent higher volatile oil content (\%) and 17.0 per cent higher seeds yield than that of best check variety GCo 2 . Newly developed variety was also found less prone to major pests and diseases during the year of testing. GCo 3 will be new choice for coriander growing farmer in the state of Gujarat.

\section{Materials and Methods}

\section{Field evaluation}

Gujarat coriander 3 (GCo 3) was tested as a code name Jcr 404. It was rigorously tested under station trials, state level trials and national trials from 2008-09 to 2014-15 at four locations across the country. For field evaluation standard Randomized Block Design (RBD) were followed. Weighted mean for seed yield over different checks varieties were calculated to find out superiority of Gujarat Coriander 3 over check varieties.

\section{Volatile Oil (\%)}

Volatile oil from coriander seeds was extracted by using distillation method (Modified Clevenger method). Weighted accurately $50 \mathrm{~g}$ of coriander seeds to yield 2 to $5 \mathrm{ml}$ of oil and transfer quantitatively to flask using water if necessary. About $500 \mathrm{ml}$ of water was added. If magnetic stirring is to be used, insert stirring bar. Assembled apparatus selecting the trap depending upon the density of the oil to be trapped. Heat the flask to boiling and maintaining a reflux of one to two drops per second. Relfuxed until two consecutive reading took at 1 hour interval showed on change of oil volume in the trap. Cooled to $20^{\circ} \mathrm{C}$ by allowing to stand. Calculated volatile oil (\%) by using following formula

Volatile oil $(\%)(\mathrm{v} / \mathrm{w})=\frac{\text { Vol. of 0il (ml) @ 20 C }}{\text { Wt. of sample (g) }} \times 100$

\section{Linalool content (\%)}

The linalool oil was extracted from air-dried powdered material $(50 \mathrm{~g})$ in glass clavengertype distillation apparatus and subjecting the material by using a method following Polish Pharmacopoeia VI guidelines (2002) and subjecting the material to hydro distillation for three hours. The extracted essential oil was stored in a dark glass container at a temperature of $-10^{\circ} \mathrm{C}$, until the time of chromatographic separation. Qualitative and quantitative analysis of the coriander linalool oil was performed using aITQ 700 GC-MS (Thermo Fisher Scientific) GC-MS instrument.

\section{Molecular marker study}

\section{Genomic DNA extraction in coriander}

The fresh leaf material of $100 \mathrm{mg}$ were collected, frozen with liquid nitrogen and stored in $-80{ }^{\circ} \mathrm{C}$ until use. DNA was extracted with CTAB method (Khanuja et al., 1999). Briefly, $1 \mathrm{~g}$ of leaf tissue was ground in liquid nitrogen by using pre-chilled mortar and pestle and transferred the material in to $15 \mathrm{~mL}$ tube. To the ground material $5 \mathrm{~mL}$ of CTAB extraction buffer was added and incubated at $60{ }^{\circ} \mathrm{C}$ for 1 hour with occasional mixing. Equal volume of chloroform: Isopropanol (1:1) mixture added and mixed well by inverting for $15 \mathrm{~min}$. Centrifuged at 12000 
rpm for $10 \mathrm{~min}$ and the aqueous layer was collected. The chromosomal DNA was collected by adding $1 \mathrm{~mL}$ of isoamylalcohol and kept at $15 \mathrm{~min}$ at room temperature. Centrifuged and the pellet transferred to a clean tube and air dried for $10 \mathrm{~min}$. DNA was dissolved in $2 \mathrm{~mL}$ of TE buffer (Tris HCL 10 $\mathrm{mM}$, EDTA $1.0 \mathrm{mM} \mathrm{pH} \mathrm{8)} \mathrm{and} \mathrm{incubated} \mathrm{at}$ $60{ }^{\circ} \mathrm{C}$ for 10 min which will dissolve DNA and inactivate DNase1. $10 \mu \mathrm{L}$ of $10 \mathrm{mg} / \mathrm{mL}$ RNase solution was added. This mixture was thoroughly mixed by inversion and incubated at $30{ }^{\circ} \mathrm{C}$ for $30 \mathrm{~min}$. To this mixture $2 \mathrm{~mL}$ of chloroform: Isoamyl alcohol (1:1) was added and centrifuged at $12000 \mathrm{rpm}$ for $10 \mathrm{~min}$. The supernatant was discarded and the precipitate washed with $70 \%$ ethanol. Then the pellet was air dried and re-dissolved in $50 \mu \mathrm{L}$ of TE buffer. Quality and quantity of DNA were checked by spectrophotometric and integrity checked by running gel electrophoresis (Fig.
2). Samples were diluted to obtain a final concentration of $20 \mathrm{ng}$ per $1 \mu \mathrm{L}$. Extraction buffer was prepared just before use. 2- $\beta$ mercaptoethanol and PVP are freshly prepared.

\section{PCR amplification for ISSR markers}

For ISSR primers, according to primer base composition, annealing temperature were found to vary. Therefore, for each primer annealing temperature was standardized. PCR mixture for ISSR analysis contained $40 \mathrm{ng}$ of genomic DNA, 1x PCR buffer, $200 \mathrm{mM}$ dNTP, primers and $1 \mathrm{U}$ of Taq polymerase. PCR conditions were $94{ }^{\circ} \mathrm{C}$ for $4 \mathrm{~min} .40$ cycles of 1 min denaturation, 1 min at $2{ }^{\circ} \mathrm{C}$ of annealing temperature specified for each primer, 2 min extension at $72^{\circ} \mathrm{C}$ and final extension for $10 \mathrm{~min}$ at $72^{\circ} \mathrm{C}$.

List of ISSR primers used for genetic diversity analysis among coriander cultivars

\begin{tabular}{cccccc} 
Sr. & \multirow{2}{*}{ Primers } & Primer Sequence & Total & Polymorphic & $\begin{array}{c}\% \text { of } \\
\text { Polymorphism }\end{array}$ \\
No & & & & 5 & 83.33 \\
1 & ISSR 17 & CACACACACACACACAA & 6 & 7 & 87.50
\end{tabular}

\section{Results and Discussion}

\section{Yield its attributes and quality parameter}

The culture Gujarat Coriander 3 (Gco 3) formally named as a Jcr 404 was collection from local market of Dahod Area, seed material was maintained and purified for three years and then proposed to PET trial. GCo3 has been tested under 12 trials for 6 years across the country. In Gujarat it was tested in two different Agro-climatic zone at Jagudan (North Gujarat) and Navsari (South Gujarat). Considering tow locations during six years, the average seed yield of GCo 3 was recorded $1501.32 \mathrm{~kg} / \mathrm{ha}$ against $1293.21 \mathrm{~kg} / \mathrm{ha}$ seed yield of state check variety Gujarat Coriander
2 (GCo 2). New variety had 17.0 per cent higher seed yield than state check variety. Among six trials at Jagudan, GCo 3 was exhibited collectively four times significantly higher yield against national and state check varieties. At North Gujarat (Jagudan) GCo3 had recorded $1843.83 \mathrm{~kg}$ seed yield, which was 9.58 per cent higher than superior check viz., GCo 2. New variety was found superior and stable at south gujarat (Navsari) location. It was performed significantly superior over national and state check varieties during three consecutive years (2012-13 to 2014-15) and recorded $1158.81 \mathrm{~kg} /$ ha seed yield against $883.74 \mathrm{~kg} / \mathrm{ha}$ against GCo 2, there was 31.12 per cent seed yield increment depicted by GCo 3. 
Table.1 Mean Seed yield (kg/ha) of proposed variety (Jcr 404) in various trials over years

\begin{tabular}{|c|c|c|c|c|c|c|c|c|c|c|c|}
\hline \multirow{2}{*}{$\begin{array}{l}\text { Name of } \\
\text { Trial/s }\end{array}$} & \multirow[t]{2}{*}{ Year/s } & \multirow[t]{2}{*}{ Locations } & \multirow[t]{2}{*}{ Jcr 404} & \multicolumn{3}{|c|}{ Check varieties } & \multicolumn{3}{|c|}{$\%$ Increase over checks } & \multirow[t]{2}{*}{ CD@ 5\% } & \multirow{2}{*}{$\begin{array}{c}\text { C.V. } \\
\%\end{array}$} \\
\hline & & & & $\begin{array}{l}\text { Hissar } \\
\text { Anand }\end{array}$ & Rer 728 & GCo 2 & $\begin{array}{l}\text { Hissar } \\
\text { Anand }\end{array}$ & Rer 728 & GCo 2 & & \\
\hline \multicolumn{12}{|c|}{ [A] Performance of Jcr-404 in North Gujarat State (Jagudan) } \\
\hline PET(IET) & 2008-09@ & \multirow{5}{*}{$\begin{array}{l}\text { North } \\
\text { Gujarat } \\
\text { (Jagudan) }\end{array}$} & 832.00 & .. & .. & 755.00 & .. & .. & 10.20 & 141.00 & 13.83 \\
\hline SSVT(IET) & $2009-10$ & & 2891.00 & .. & .. & 2406.00 & .. & .. & 20.16 & NS & 15.04 \\
\hline LSVT(IET) & 2010-11 & & $1848.00 * \#$ & .. & .. & 1574.00 & .. & .. & 17.41 & 230.00 & 07.74 \\
\hline \multirow[t]{2}{*}{ LSVT(IET) } & 2011-12 & & 1105.00 & .. & .. & 1432.00 & & & -22.84 & 248.00 & 11.78 \\
\hline & Mean & & 1948.00 & .. & .. & 1804.00 &.. & .. & 4.91 & 185.50 & -- \\
\hline \multirow{4}{*}{$\begin{array}{l}\text { National trial } \\
\quad(\text { CVT })\end{array}$} & $2012-13$ & \multirow{4}{*}{$\begin{array}{l}\text { North } \\
\text { Gujarat } \\
\text { (Jagudan) }\end{array}$} & $1448.00^{* \dagger}$ & 1206.00 & 832.00 & 1328.00 & 20.07 & 44.95 & 9.04 & 185.00 & 8.51 \\
\hline & 2013-14 & & $1514.00^{* \hbar \#}$ & 1102.00 & 806.00 & 1287.00 & 37.39 & 36.72 & 17.64 & 205.00 & 10.80 \\
\hline & 2014-15 & & $2257.00^{* \dagger}$ & 1827.00 & 1123.00 & 2069.00 & 23.54 & 62.69 & 9.09 & 349.00 & 11.34 \\
\hline & Mean & & 1739.67 & 1378.33 & 920.33 & 1561.33 & 27.00 & 48.12 & 11.42 & 246.33 & -- \\
\hline \multicolumn{3}{|c|}{ Mean of Check varieties (A) } & & 1378.33 & 920.33 & 1682.67 & & & & & \\
\hline \multicolumn{3}{|c|}{$\begin{array}{l}\text { Mean (Jcr-404) / Weighted mean (Jcr-404) } \\
\text { against respective checks (A) }\end{array}$} & 1843.83 & $\underline{1739.67}$ & $\underline{1739.67}$ & $\underline{1843.83}$ & & & & & \\
\hline \multicolumn{3}{|c|}{$\%$ increase against respective checks } & & 26.22 & 89.03 & 9.58 & & & & & \\
\hline \multicolumn{12}{|c|}{ [B] Performance of Jcr-404 in South Gujarat State (Navsari) } \\
\hline \multirow{4}{*}{$\begin{array}{l}\text { National trial } \\
\quad(\mathrm{CVT})\end{array}$} & 2012-13 & \multirow{4}{*}{$\begin{array}{l}\text { South } \\
\text { Gujarat } \\
\text { (Navsari) }\end{array}$} & $1220.25^{*+\#}$ & 837.53 & 746.67 & 901.23 & 45.70 & 63.43 & 35.40 & 131.87 & 10.14 \\
\hline & 2013-14 & & $1231.48^{* \# \#}$ & 888.89 & 780.86 & 922.84 & 38.54 & 57.71 & 33.44 & 134.27 & 11.37 \\
\hline & $2014-15$ & & $1024.69^{\dagger \#}$ & 1043.21 & 753.09 & 827.16 & -1.78 & 36.06 & 23.88 & 96.78 & 06.85 \\
\hline & Mean & & 1158.81 & 923.21 & 760.21 & 883.74 & 25.52 & 52.43 & 31.12 & 73.96 & -- \\
\hline \multicolumn{3}{|c|}{ Mean of Check varieties (B) } & & 923.21 & 760.21 & 883.74 & & & & & \\
\hline \multicolumn{3}{|c|}{$\begin{array}{l}\text { Mean (Jcr-404) / Weighted mean (Jcr-404) } \\
\text { against respective checks (B) }\end{array}$} & 1158.81 & $\underline{\mathbf{1 1 5 8 . 8 1}}$ & $\underline{1158.81}$ & $\underline{1158.81}$ & & & & & \\
\hline \multicolumn{3}{|c|}{$\%$ increase against respective checks } & & 25.52 & 52.43 & 31.12 & & & & & \\
\hline \multicolumn{3}{|c|}{ Mean of Check varieties $(A+B)$} & & 1150.77 & 840.27 & 1283.21 & & & & & \\
\hline \multicolumn{3}{|c|}{$\begin{array}{l}\text { Mean }(\mathrm{Jcr}-404) / \\
\text { Weighted mean }(\mathrm{Jcr}-404) \text { against respective } \\
\text { checks }(\mathrm{A}+\mathrm{B})\end{array}$} & 1501.32 & $\underline{1449.24}$ & $\underline{1449.24}$ & $\underline{1501.32}$ & & & & & \\
\hline \multicolumn{3}{|c|}{$\%$ increase against respective checks } & & 25.94 & 72.47 & 17.00 & & & & & \\
\hline \multicolumn{3}{|c|}{ No. of trial frequency (Gujarat) } & 9 & 6 & 6 & 9 & & & & & \\
\hline \multicolumn{3}{|c|}{ No. of frequency in superiority } & & $5 / 6$ & $6 / 6$ & $5 / 9$ & & & & & \\
\hline
\end{tabular}

Note: @ = Data of 2008 -09 (PET/IET) not considered due to below state average yield

Under line figures represents weighted mean of proposed culture Jcr 404 against respective checks

$*, \dagger$ and \# are indicating significant over Hissar Anand, Rcr 728 and GCo 2, respectively

Conti...... 


\begin{tabular}{|c|c|c|c|c|c|c|c|c|c|c|c|}
\hline \multirow{2}{*}{$\begin{array}{c}\text { Name of } \\
\text { Trial/s }\end{array}$} & \multirow[t]{2}{*}{ Year/s } & \multirow[t]{2}{*}{ Locations } & \multirow[t]{2}{*}{ Jcr 404} & \multicolumn{3}{|c|}{ Check varieties } & \multicolumn{3}{|c|}{$\%$ Increase over checks } & \multirow{2}{*}{$\begin{array}{c}\text { CD@ } \\
5 \%\end{array}$} & \multirow{2}{*}{$\begin{array}{c}\text { C.V. } \\
\%\end{array}$} \\
\hline & & & & $\begin{array}{l}\text { Hissar } \\
\text { Anand }\end{array}$ & Rer 728 & GCo 2 & $\begin{array}{l}\text { Hissar } \\
\text { Anand }\end{array}$ & $\begin{array}{l}\text { Rcr } \\
728\end{array}$ & $\begin{array}{c}\text { GCo } \\
2\end{array}$ & & \\
\hline \multicolumn{12}{|c|}{ [C] Performance of Jcr-404 in major coriander growing states of India } \\
\hline \multirow{4}{*}{$\begin{array}{l}\text { National } \\
\text { trial } \\
(\mathrm{CVT}) \mathrm{s}\end{array}$} & $2012-13$ & \multirow{4}{*}{$\begin{array}{c}\text { Hissar } \\
\text { (Haryana) }\end{array}$} & $1825.10^{\dagger}$ & 1761.70 & 1560.10 & .. & 3.60 & 16.99 & .. & 69.40 & 12.48 \\
\hline & 2013-14 & & $1849.40^{\dagger}$ & 1852.70 & 1734.60 & .. & -0.18 & 6.62 & .. & 51.80 & 14.54 \\
\hline & $2014-15$ & & $1806.50^{*}$ & 1735.20 & 1872.60 & .. & 4.11 & -3.53 & .. & 60.50 & 13.25 \\
\hline & Mean & & 1827.00 & 1783.20 & 1722.43 & .• & 2.46 & 6.07 & .. & 60.57 & -- \\
\hline \multirow{4}{*}{$\begin{array}{l}\text { National } \\
\text { trial } \\
(\mathrm{CVT})\end{array}$} & $2012-13$ & \multirow{4}{*}{$\begin{array}{c}\text { Jobner } \\
\text { (Rajasthan) }\end{array}$} & 1958.33 & 1842.59 & 1912.04 & .. & 6.28 & 2.42 & .. & 402.88 & 12.70 \\
\hline & 2013-14 & & $1513.89^{* \dagger}$ & 1305.56 & 1143.52 & .. & 15.96 & 32.39 & .. & 207.12 & 10.77 \\
\hline & 2014-15 & & 2368.98 & 2085.19 & 2760.65 & .. & 13.61 & -14.19 & .. & 384.90 & 10.19 \\
\hline & Mean & & 1947.07 & 1744.45 & 1938.74 & .• & 11.62 & 0.43 & .• & 331.63 & -- \\
\hline \multicolumn{3}{|c|}{ Mean of check varieties (C) } & & 1763.82 & 1830.59 & & & & & & \\
\hline \multicolumn{3}{|c|}{$\begin{array}{l}\text { Mean }(\mathrm{Jcr}-404) / \\
\text { Weighted mean (Jcr-404) against respective } \\
\text { checks (C) }\end{array}$} & 1887.03 & $\underline{1887.03}$ & $\underline{1887.03}$ & & & & & & \\
\hline \multicolumn{3}{|c|}{$\%$ increase against respective checks } & & 6.99 & 3.08 & & & & & & \\
\hline \multicolumn{3}{|c|}{$\begin{array}{l}\text { Frequency of significant over respective checks } \\
\text { in rest of India }\end{array}$} & & 2 Times & 3Times & & & & & & \\
\hline \multicolumn{3}{|c|}{ No.of Trial frequency ( C) } & 6 & 6 & 6 & & & & & & \\
\hline \multicolumn{3}{|c|}{ Over all Mean of Check varieties $(\mathrm{A}+\mathrm{B}+\mathrm{C})$} & & 1457.30 & 1335.43 & 1283.21 & & & & & \\
\hline \multicolumn{3}{|c|}{$\begin{array}{l}\text { Over all mean/ weighted mean of } \\
\text { Jcr-404 against respective checks }(A+B+C)\end{array}$} & 1694.18 & $\underline{1668.14}$ & $\underline{1668.14}$ & $\underline{1501.32}$ & & & & & \\
\hline \multicolumn{3}{|c|}{$\%$ increase against respective checks } & & 14.47 & 24.91 & 17.00 & & & & & \\
\hline \multicolumn{3}{|c|}{ Total No. of Trial Frequency $(A+B+C)$} & 15 & 12 & 12 & 9 & & & & & \\
\hline \multicolumn{3}{|c|}{$\begin{array}{l}\text { No. of frequency in superiority } \\
(A+B+C)\end{array}$} & & $7 / 12$ & 9/12 & $5 / 9$ & & & & & \\
\hline
\end{tabular}

$\dagger$ and \# are indicating significant over Hissar Anand, Rcr 728 and GCo 2, respectively.

Source: Annual reports and AICRPS reports 
Table.2 Mean performance of volatile oil content (\%) and volatile oil yield (1/ha) of Jcr 404

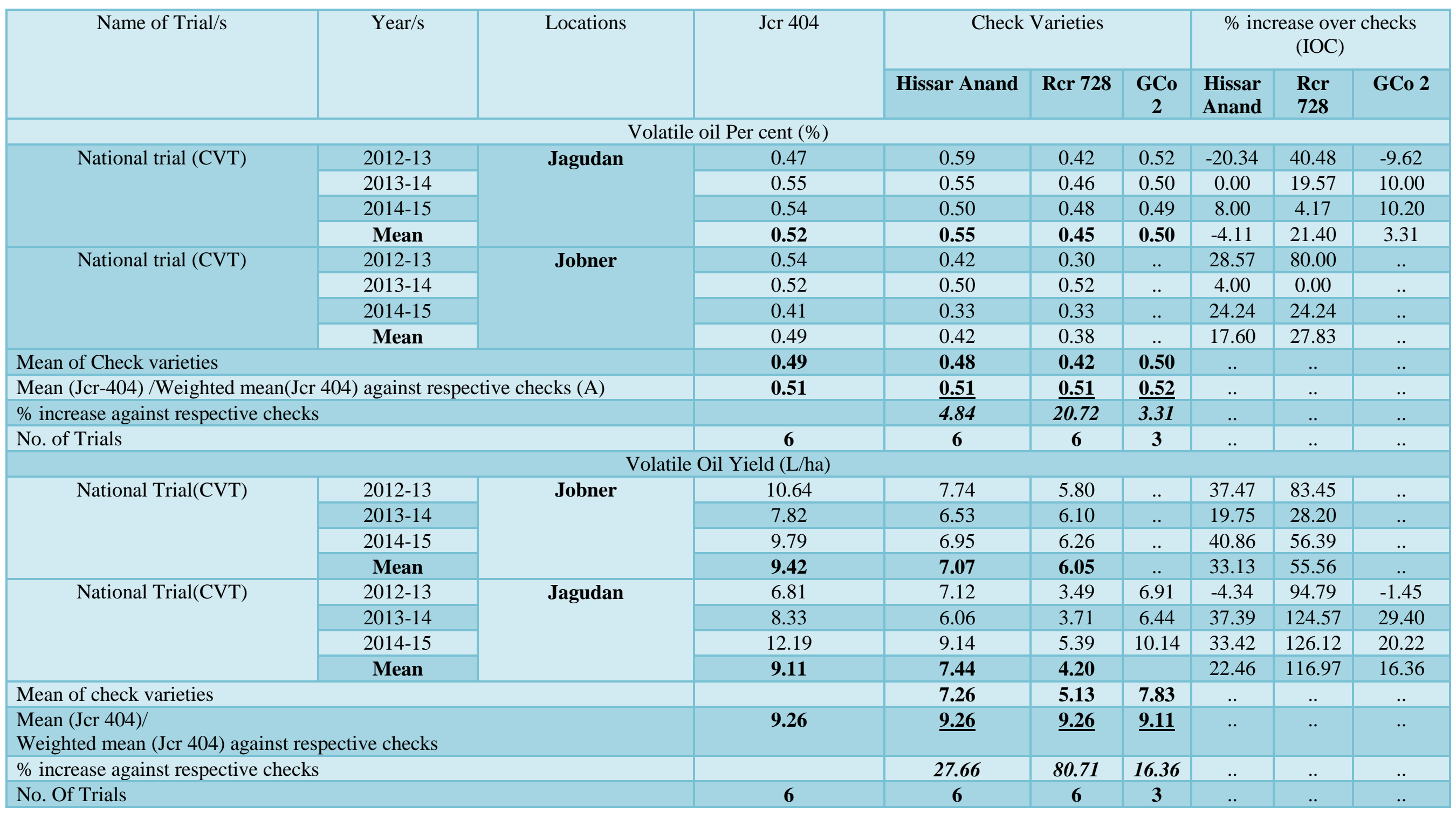


Table.3 Test results for linalool content (\%w/w) in Gujarat Coriander 3

\begin{tabular}{|c|c|c|c|c|}
\hline Variety & Lab ID & R-I & R-II & R-III \\
\hline GCo3 & Co/2016/40-1 & 73.15 & 72.28 & 71.05 \\
\hline GCo2 & Co/2016/40-1 & 64.77 & 66.41 & 66.61 \\
\hline
\end{tabular}

Table.4 Ancillary characters of proposed variety Jcr 404

\begin{tabular}{|c|c|c|c|c|c|c|c|c|c|}
\hline \multirow[t]{2}{*}{ Traits } & \multirow[t]{2}{*}{ Jcr 404} & \multirow{2}{*}{$\begin{array}{l}\text { Hissar } \\
\text { Anand }\end{array}$} & \multirow[t]{2}{*}{ Rcr 728} & \multirow[t]{2}{*}{ GCo 2} & \multicolumn{3}{|c|}{$\%$ increase over checks } & \multirow[t]{2}{*}{ S.Em. } & \multirow[t]{2}{*}{ C.D@ $5 \%$} \\
\hline & & & & & Hissar Anand & Rer 728 & GCo 2 & & \\
\hline Days to $50 \%$ Flowering & 54.33 & 58.33 & 66.33 & 55.33 & -6.86 & -18.09 & -1.81 & 0.67 & 1.96 \\
\hline Maturity Days & 113.00 & 115.00 & 121.67 & 114.33 & -1.74 & -7.12 & -1.17 & 0.59 & 1.72 \\
\hline Branch/ Plant & 7.23 & 5.73 & 5.10 & 5.97 & 26.16 & 41.83 & 21.23 & 0.17 & 0.50 \\
\hline Umbel/ Plant & 28.53 & 23.50 & 17.67 & 23.67 & 21.42 & 61.51 & 20.56 & 1.11 & 3.23 \\
\hline Umbellate/Umbel & 6.93 & 6.10 & 5.90 & 6.47 & 13.66 & 17.51 & 7.22 & 0.21 & 0.62 \\
\hline Seeds/Umbellate & 8.80 & 6.53 & 9.17 & 8.57 & 34.69 & -4.00 & 2.72 & 0.36 & 1.04 \\
\hline Seeds/Umbel & 55.23 & 40.50 & 52.97 & 49.85 & 36.38 & 4.28 & 10.80 & 2.61 & 7.65 \\
\hline Test wt. (gm) & 10.82 & 10.97 & 7.39 & 10.35 & -1.39 & 46.37 & 4.56 & 0.14 & 0.40 \\
\hline
\end{tabular}

Table.5 Reaction against major pests and diseases of proposed variety Jcr 404

\begin{tabular}{|c|c|c|c|c|c|c|}
\hline \multicolumn{7}{|l|}{ Pests } \\
\hline \multirow[t]{2}{*}{ Genotype } & \multicolumn{6}{|c|}{ Mean Aphid Index For Three Years } \\
\hline & 2012-13 & 2013-14 & 2014-15 & Total & \multicolumn{2}{|c|}{ Mean } \\
\hline Jcr 404 & 0.64 & 0.48 & 0.74 & 1.84 & \multicolumn{2}{|c|}{0.62} \\
\hline GCo $2(\mathrm{Ch})$ & 1.68 & 1.63 & 1.47 & 4.48 & \multicolumn{2}{|c|}{1.59} \\
\hline \multicolumn{7}{|l|}{ Disease } \\
\hline \multicolumn{4}{|c|}{ Powdery Mildew Index (PDI) for Three years } & \multicolumn{3}{|c|}{ Stem gall infestation for three years } \\
\hline Genotype & 2012-13 & 2013-14 & 2014-15 & 2012-13 & 2013-14 & 2014-15 \\
\hline Jer 404 & 15.10 & 11.25 & 9.50 & 0.00 & 0.00 & 0.00 \\
\hline GCo $2(\mathrm{Ch})$ & 30.26 & 21.00 & 19.70 & 0.00 & 0.00 & 0.00 \\
\hline
\end{tabular}


Fig.1 Linalool - terpene alcohol, compound with anti inflammatory, antimicrobial and sedative properties

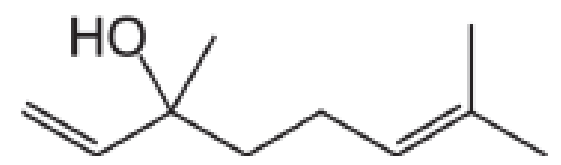

Fig.2 Genomic DNA of Coriander

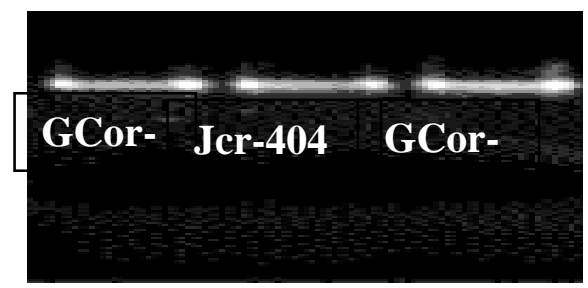

Fig.3 ISSR profile of three different coriander cultivars amplified with ISSR primers AAU-CEBISSR 17 \& AAU-CEB-ISSR 86

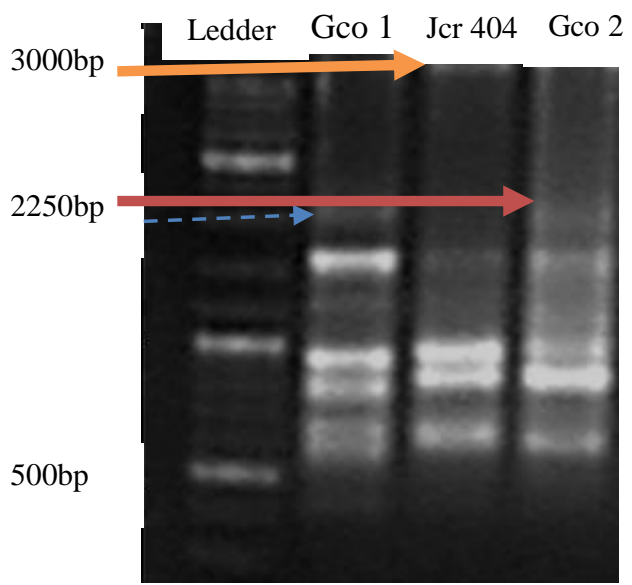

AAU-CEB-ISSR 17

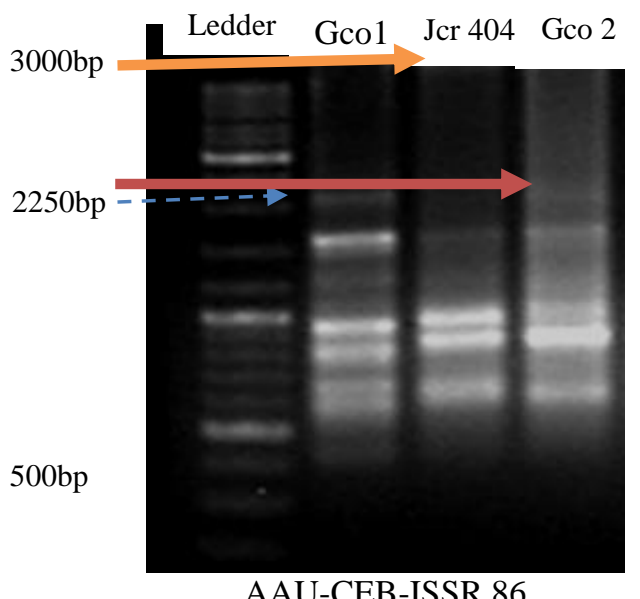

respect to volatile oil content (\%), Gujarat Coriander 3 found 4.84, 20.72 and 3.31 per cent superior than two national checks and state check varieties, respectively. In connection to this, during the years of experiments, GCo 3 was reported $9.26 \mathrm{lt} / \mathrm{ha}$ volatile oil yield which was $27.66,80.71$ and 16.36 per cent higher than that of Hissar Anand (7.26 lt.), Rcr 728 (5.13 lt.) and GCo 2 (7.83 lt), respectively (Table 2). Linalool is natural occurring alkaloids synthesize in coriander seeds, which is responsible for fragrance in coriander seed. Excellent aroma 
presents in seeds of GCo 3, due to 8.36 per cent higher linalool content $(72.16 \%)$ than that of check variety G Co 2 (66.59\%) (Table 3 and Fig. 1). A variety GCo 3 least infected by aphid and marginal infestation of powdery mildew was found during the years of testing under co-ordinated trials (Table 4).

\section{Molecular studies}

Two ISSR primer viz., ISSR-17 and ISSR -86 were finally screen for detection of variability among three cultivar of coriander which includes new release variety Gujarat Coriander 3 and two checks (GCo 1 and GCo 2). Primer ISSR 17 and ISSR 86 had reported 83.33 and 87.50 per cent polymorphism. Reproducibility of both primers were also occurred with high frequency. A distinguished fragment of $3000 \mathrm{bp}$ appeared in Gujarat coriander 3 only, which signifies that, the cultivar under study is having enough genetic distance than that of both reference varieties (Figure 3).

Seed yield is not a single character but it is conglomerate of many characters, ancillary observation like braches per plant, Umbel/ Plant, Umbellate/Umbel, Seeds/Umbellate, Seeds/Umbel and Test wt. (gm) are directly influences on seed yield. Gujarat Coriander 3 variety is found superior for all these characters than that of check varieties (Islam et al., 2003; Dyulgerov et al., 2013; Mert et al., 1998). In respect to earliness, variety GCo3 was found quite early maturing than all three check varieties, because of early maturity escape mechanism may play role for major diseases and pests are concern. The variety GCo3 may tolerant to aphid and powdery mildew due to early maturity (Table 4 and 5). The variety is having purple colour pigmentation in pollen and petals of flowers. This is one of DUS (Distinguished Uniform and Stable) character to identify variety, the purple pigmentation may also responsible for synthesise high amount of linalool in seed at maturity (Meena et al., 2013 and Renata et al., 1998). Coriander variety with white pollen and petal has always recorded lower linalool than that coriander variety with purple pollen and petal (Dyulgerov et al., 2013).

Under molecular examination, Primer ISSR 17 and ISSR 86 had exhibited more than 80 per cent polymorphism. All three varieties distinguished at 3000 bp fragments, which means that the source and genetic materials were different in all three varieties at the time of selection (Al-Kordy et al., 2013).

In conclusion, Gujarat Coriander 3 (GCo 3) was recommended for release after 28 years in Gujarat state. GCo 3 had recorded 1501.32 $\mathrm{kg} / \mathrm{ha}$ seed yield, which was 17.00 per cent higher seed yield than check variety Gujarat Coriander 2 (GCo 2), which directly increase yield and revenue of the farmers from unit area. Absolute linalool is used by pharmaceuticals, food and cosmetic industries. Due to high linalool conten, market rate of GCo3 seeds will also more than other ordinary variety, which will be directly benefited to the farmers. GCo3 will become good choice for export oriented coriander cultivation. To make curry powder a seed with high linalool content always demanding by exporters. In nutshell, GCo3 is complete package with seed yield and quality.

\section{References}

Al-Kordy M.A.A., Abou El-Nasr T.H.S. and Sherin A. Mahfouze 2013. Assessing Phenotypic and Molecular Variability in Coriander (Coriandrum sativum L.) Cultivars. Journal of Applied Sciences Research, 9(6): 3880-3889

Dyulgerov, N. and B. Dyulgerov. 2013. Variation of yield components in coriander (Coriandrum sativum L.). 
Agricultural Science and Technology, 5(2): $160-163$.

Islam, M.S., M.A. Rahman, M.M. Mazumder, R.K. Hossain, M.A.J. Bhuyan. 2004. Performance of some coriander genotypes for grain yield and its attributes. Bangladesh J. Agril. Res. 29(1): 59-66.

Khanuja S.P., Shasany, A.K., Darokar, M. 1999. DNA extraction method from plant tissue. Plant Molecular Biology Reporter, 17:66

Meena, B.S., B.L. Dhaka and M.K. Poonia. 2013. Assessment of yield, quality and economics of coriander (Coriandrum sativum L.) genotypes in south-eastern plains of Rajasthan under irrigated condition. International Journal of Seed Spices, 3: 58-60
Mert, A. and S. Kirici. 1998. To determine the yield and yield characters of coriander (Coriandrum sativum L.) populations. Proceedings of XIIth International Symposium on Plant Originated Crude Drugs, New Trends and Methods in Natural Products Research. May, 2022, Ankara, Abstract Book: 112.

Polish pharmacopeia VI 200). Polskie towas zystevo farmaceutyczne warszawa.

Renata Nurzyńska-Wierdak 2012. Essential oil composition of the coriander (Coriandrum sativum L.) Herb depending on the development stage. Acta Agrobotanica, 66 (1): 53-60

Report of director of horticulture, government of Gujarat 2015-16:7.

Report of Spice Board of India 2015-16.

\section{How to cite this article:}

Patel,' H.B., D.G. Patel, P.T. Patel, N.R. Patel, Hitesh Patel and Amin, A.U. 2018. Gujarat Coriander 3- A Complete Package with High Seed Yield and Aroma. Int.J.Curr.Microbiol.App.Sci. 7(08): 3736-3745. doi: https://doi.org/10.20546/ijcmas.2018.708.379 